\title{
FUNCTIONAL INDEPENDENCE OF PEDIATRIC PATIENTS WITH MUCOPOLYSACCHARIDOSES
}

\author{
INDEPENDÊNCIA FUNCIONAL DE PACIENTES PEDIÁTRICOS \\ COM MUCOPOLISSACARIDOSES
}

\author{
Paloma Silva lopes, ${ }^{1}$ Diógenes Pires Serra Filho, ${ }^{1}$ Marcos antônio almeida Matos ${ }^{1,2}$ \\ 1. Escola Bahiana de Medicina e Saúde Pública (EBMSP), Salvador, BA, Brazil. \\ 2. Santa Casa de Misericórdia da Bahia, Salvador, BA, Brazil.
}

\begin{abstract}
Objective: To measure the functional independence to perform activities of daily living of pediatric patients diagnosed with mucopolysaccharidoses. Methods: A descriptive cross-sectional study was carried out with the population of pediatric patients with a confirmed enzymatic diagnosis of mucopolysaccharidoses, enrolled in the Orthopedics outpatient clinic of a hospital in the State of Bahia. The data were collected between October 2016 and March 2017, based on the documentary analysis of the assessment forms used in the department. The variables of this study comprised sex, age, type of MPS and level of functional independence, measured by the Functional Independence Measure scale. Results: Twenty-six patients participated in the study. These were predominantly male (61.5\%), with a mean age of $10 \pm 4.5$ years, affected by MPS VI (73.1\%). In the motor domain, the mean score was $65( \pm 19.9$ points); the cognitive domain obtained a mean score equal to 28 ( \pm 8.2 points); and the total FIM score was 93 ( \pm 26.5 ). Conclusion: Impaired functional independence was observed among children and adolescents with mucopolysaccharidoses. Tasks related to dressing, toileting, bathing, problem solving and social interaction were those that required the most assistance and/or supervision. Level of Evidence IV, Case Series.
\end{abstract}

Keywords: Mucopolysaccharidoses. Activities of daily living. Children with disabilities.

\section{RESUMO}

Objetivo: Medir a independência funcional para realização de Atividades de Vida Diária de pacientes pediátricos diagnosticados com mucopolissacaridoses (MPS). Métodos: Estudo transversal, descritivo, realizado com a população de pacientes pediátricos com diagnóstico enzimático confirmado de mucopolissacaridoses, cadastrados no ambulatório de ortopedia de um hospital no Estado da Bahia. Os dados foram coletados entre outubro de 2016 e março de 2017, a partir da análise documental das fichas de avaliação utilizadas no serviço. As variáveis deste estudo compreenderam sexo, idade, tipo de MPS e nível de independência funcional, mensurado pela escala de Medida de Independência Funcional. Resultados: Participaram do estudo 26 pacientes, que eram predominantemente do sexo masculino (61,5\%), com média de idade de $10 \pm 4,5$ anos, acometidos por mucopolissacaridoses VI (73,1\%). No domínio motor, a pontuação média foi 65 ( \pm 19,9 pontos); o domínio cognitivo obteve escore médio igual a 28 ( \pm 8,2 pontos); e o escore total da MIF foi 93 ( $\pm 26,5)$. Conclusão: Foi observado comprometimento da independência funcional de crianças e adolescentes com mucopolissacaridoses. Tarefas relacionadas ao vestuário, utilização do vaso sanitário, banho, resolução de problemas e interação social foram as que demandaram maior assistência e/ou supervisão. Nível de Evidência IV, Série de Casos.

Descritores: Mucopolissacaridoses. Atividades Cotidianas. Crianças com incapacidade.

Citation: Lopes PS, Serra Filho DP, Matos MAA. Functional independence of pediatric patients with mucopolysaccharidoses. Acta Ortop Bras. [online] 2019;27(4):212-5. Available from URL: http://www.scielo.br/aob.

\section{INTRODUCTION}

Mucopolysaccharidoses (MPS) are a group of rare hereditary metabolic diseases characterized by a defect in glycosaminoglycan metabolism, secondary to the inactivity of specific enzymes necessary for its degradation.1,2 Intralysosomal accumulation of glycosaminoglycans, caused by enzyme deficiency, generates several chronic and progressive alterations that result in changes in the lives of affected subjects and their families., ${ }^{1,3}$
There are seven types of mucopolysaccharidoses described in the literature, classified on the basis of the deficient enzyme or accumulated glycosaminoglycan, and that can also vary in terms of phenotype - from attenuated to severe. ${ }^{1,4}$ The clinical features resulting from mucopolysaccharidoses include skeletal, joint, cardiorespiratory, neurological, auditory and visual alterations that vary according to the disease type., ${ }^{1,3}$ In patients with mucopolysaccharidoses, the somatic manifestations produce a profile marked by bone deformities, joint limitation,

All authors declare no potential conflict of interest related to this article.

Work conducted at the Escola Bahiana de Medicina e Saúde Pública/Santa Casa de Misericórdia da Bahia, Salvador, BA, Brazil.

Correspondence: Paloma Silva Lopes. Av. Maria Quitéria, n.o 81, Brasília, Feira de Santana, BA, Brazil. 44088-000. palomaslopes82@gmail.com/palomalopes.pos@bahiana.edu.br 
chest cavity abnormalities, short stature and hip dysplasia, as well as deformities in knee flexion and of the interphalangeal joints. ${ }^{5,6}$ Patients may also develop obstructive respiratory disorders (such as obstructive sleep apnea and narrowing of the upper airways, caused by the accumulation of thick mucus resulting from recurrent infectious processes); or restrictive disorders due to thoracic stiffness and abdominal distension associated with thoracic deformities. ${ }^{5,7}$ The nervous system is also commonly affected in some types of MPS, and results in the occurrence of neural and/or spinal cord compression, eventually leading to cognitive impairment. ${ }^{8,9}$ These changes are progressive and have a significant impact on the functional independence of the individuals affected. ${ }^{10}$

Research on functional impairment resulting from mucopolysaccharidosis mostly originates in developed countries, ${ }^{11,12}$ made up of populations with sociocultural characteristics that differ from the Brazilian population and supported by a better social network and health care. In Brazil and other developing countries, research on these diseases is still in the early stages.

Accordingly, the aim of this study was to measure functional independence in the performance of activities of daily living in pediatric patients diagnosed with mucopolysaccharidoses. An understanding of the functional performance of these patients may help health professionals, specifically those in the field of rehabilitation, to define the demand for necessary healthcare and improve intervention strategies for this population.

\section{MATERIAL AND METHODS}

A descriptive cross-sectional study was carried out with the population of pediatric patients with a confirmed enzymatic diagnosis of mucopolysaccharidoses, enrolled in the orthopedic outpatient clinic of a reference hospital in the city of Salvador, state of Bahia.

This study is linked to the project "Clinical assessment of musculoskeletal features in patients with mucopolysaccharidoses". In compliance with the Guidelines and Standards for Research on Human Subjects contained in Resolution 466/2012 of the Brazilian National Board of Health, the project was submitted to the Institutional Review Board and approved under CAAE [Certificate of Submission for Ethical Consideration] no. 38746914.5.0000.5520/Opinion no. 1.672.503.

Subjects enrolled in the study were all the male and female children and adolescents aged 2-18 years who were receiving medical outpatient follow-up care between January 2012 and October 2014, except those diagnosed with another active chronic or exacerbated condition not associated with mucopolysaccharidosis, and those whose parents/guardians did not sign the Informed Consent Form. The data were collected from October 2016 to March 2017, based on the documentary analysis of the standardized assessment forms used in the department. The variables of this study included sex (stratified in female and male); age (evidenced in years); type of MPS (categorized according to the disease types described in the literature); and functional independence level measures (evidenced by numerical score, according to the specific instrument used).

To assess the level of independence, the instrument used in the abovementioned department was the Brazilian version of the Functional Independence Measure (FIM). ${ }^{13,14}$ This is a generic assessment tool, consisting of 18 items which fall into two domains. The motor domain (13 items) evaluates four functional dimensions: self-care, sphincter control, transfer and locomotion; and the cognitive domain (5 items) evaluates two dimensions: communication and social cognition. ${ }^{14}$ The FIM identifies how much help the individual requires to accomplish daily tasks, whether it is the assistance of another person or the use of an adaptation resource; and quantitatively measures the level of functional independence of the subject being assessed. ${ }^{14}$
The scoring of the items of the FIM instrument follows an ordinal scale of dependence graded at seven levels: 1 corresponds to the need for total assistance to perform the task and 7 to complete independence for the activity. The sum of points assigned to each item corresponds to the scores of the respective domains and the total score of the instrument. The motor domain ranges from 13 to 91 points; the cognitive domain, from 5 to 35 points; and the total score from 18 to 126 points. The lower the score, the greater the need for assistance to perform the task. ${ }^{13,14}$ At the facility where this study was conducted, the FIM scale was applied by a trained professional at the time of patient admission, through an individual interview held with the parents, following the guidelines of the manual for this instrument. ${ }^{13}$ Following an analysis of the normal distribution of the numerical data using the Kolmogorov-Smirnov test, the continuous variables were described in mean $(\mu)$ and standard deviation $( \pm S D)$, and the categorical variables in absolute and relative frequency. The analyses were carried out using version 20.0 of the statistical program $\mathrm{BBM}^{\circledR}$ SPSS ${ }^{\circledR}$ Statistics.

\section{RESULTS}

Over the study period, 26 children and adolescents diagnosed with mucopolysaccharidoses were monitored in the orthopedic department of the abovementioned hospital. Male subjects with age averaging $10 \pm 4.5$ years affected by MPS type VI (73.1\%) predominated (61.5\%). (Table 1)

The results of the functional independence measure of the performance of activities of daily living show that in the motor domain, self-care was the subdomain with the lowest score - it reached $62 \%$ of the highest possible score (26 28.3 points). (Table 2 ) The activities in which the children and adolescents with MPS required most assistance or supervision in this subdomain were related to dressing, bathing and toileting. (Table 3)

Table 1. Sociodemographic and clinical characteristics of children and adolescents with MPS monitored at an Orthopedic outpatient clinic in the city of Salvador, Bahia, from January 2012 to October 2014.

\begin{tabular}{c|c}
\hline Variables & $\mathbf{N}(\%)$ or Mean SD \\
\hline Sex & $10(38.5 \%)$ \\
\hline Female & $16(61.5 \%)$ \\
\hline Male & 104.5 \\
\hline Age (in years) & \\
\hline Type of MPS & $1(3.8 \%)$ \\
\hline I & $4(15.4 \%)$ \\
\hline II & $2(7.7 \%)$ \\
\hline IV & $19(73.1 \%)$ \\
\hline $\mathrm{VI}$ &
\end{tabular}

Caption (Table 1): MPS -Mucopolysaccharidosis; SD - Standard deviation. Source: Salvador-BA, 2017.

Table 2. Scores of the dimensions/domains and total score of the FIM scale applied to the parents of children and adolescents monitored at an Orthopedic outpatient clinic in the city of Salvador, Bahia, from January 2012 to October 2014.

\begin{tabular}{c|c|c}
\hline Dimensions of the FIM Scale & Mean SD & $(\%)^{*}$ \\
\hline Motor Domain & 6519.9 & $71 \%$ \\
\hline Self-care & 268.3 & $62 \%$ \\
\hline Sphincter control & 123.5 & $86 \%$ \\
\hline Transfers & 176.6 & $81 \%$ \\
\hline Locomotion & 104.8 & $71 \%$ \\
\hline Cognitive Domain & 288.2 & $80 \%$ \\
\hline Communication & 123.7 & $86 \%$ \\
\hline Social cognition & 164.9 & $76 \%$ \\
\hline Total Score of FIM & 9326.5 & $74 \%$ \\
\hline
\end{tabular}

Caption (Table 2): SD - Standard deviation; FIM -Functional Independence Measure; *-Percentage of the mean score obtained, in comparison to the highest possible score of the dimension/domain. Source: Salvador-BA, 2017. 
In the cognitive domain, social cognition reached $76 \%$ of the highest possible score (16 \pm 4.9 points). (Table 2) Among the activities that constitute this subdomain, the subjects participating in the study needed more assistance in problem solving and social interaction. (Table 3)

\section{DISCUSSION}

The findings of this study indicated impairment of the functional independence of children and adolescents diagnosed with mucopolysaccharidoses, primarily in relation to motor function when compared to cognitive function. The most significant motor impairment was self-care activities, including dressing, bathing, and toilet hygiene.

The second lowest score was obtained in the locomotion subdomain (71\% of the highest possible score), suggesting that patients with MPS develop difficulty walking, a factor that further accentuates the level of dependence among these subjects. The findings of this research project corroborate the general clinical characteristics described in the literature, regarding the significant decline in motor function evidenced in cases of mucopolysaccharidoses. 4,10,15 We believe that the alteration of hand function in patients with MPS, secondary to finger flexion deformities (claw hands) and joint stiffness, hinders the performance of daily activities, especially those that require manual ability, and has a direct impact on the functional performance of these individuals. ${ }^{1,11}$ When studying the occurrence of carpal tunnel syndrome in children diagnosed with MPS type II, Know et al. ${ }^{16}$ stated that this condition has a genetic etiology; and late diagnosis, due to the more severe involvement of other organs followed by skeletal dysplasia and joint stiffness, contributes to the complete loss of hand function. ${ }^{16}$

Since some daily activities require mobility and/or manual strength, we cogitate whether the greater the involvement of the hand, the greater the need for assistance in performing them, and consequently the greater the difficulties in self-care, since this domain includes activities that normally require the use of the upper extremities.

Cognitive status is another factor that interferes in functional performance and, consequently, in the independence to perform activities of daily living, as the integrity of this component is related to the understanding of what should be done when faced with a particular task to be performed. ${ }^{17}$ Abnormal cognitive function is a distinct characteristic of all forms of MPS type III, and may also occur in patients with the severe form of MPS types I and II, and in MPS VII, ${ }^{1}$ justifying the limitation in the ability of these individuals to perform their daily activities.

In this study, the prevalence of patients diagnosed with MPS VI, which does not involve cognitive impairment, may have contributed to a higher score in this domain. However, although the cognitive status of the children and adolescents participating in this research project reached a higher score than motor status, the mean of this domain was about $20 \%$ lower than the highest possible score, suggesting a certain degree of cognitive alteration in the sample studied.

In mucopolysaccharidosis, the accumulation of glycosaminoglycans in the central nervous system, the development of hydrocephalus and the presence of sleep disorders, such as obstructive apnea and sustained hypoventilation, are factors that may impair brain function and, therefore, cognitive learning, with negative repercussions on the functional state of patients. ${ }^{18}$

Table 3. Distribution of children and adolescents with mucopolysaccharidoses monitored at an Orthopedic outpatient clinic in the city of Salvador, Bahia, from January 2012 to October 2014, according to levels of dependence on the FIM scale.

\begin{tabular}{|c|c|c|c|c|c|c|c|}
\hline \multirow{2}{*}{ Subdomains of the FIM Scale } & \multicolumn{7}{|c|}{ SCORES† } \\
\hline & 1 & 2 & 3 & 4 & 5 & 6 & 7 \\
\hline & \multicolumn{7}{|c|}{$\mathrm{N}(\%)$} \\
\hline \multicolumn{8}{|l|}{ Self-care } \\
\hline Eating & $1(3.8 \%)$ & $2(7.7 \%)$ & & $1(3.8 \%)$ & $4(15.4 \%)$ & $11(42.3 \%)$ & $7(27 \%)$ \\
\hline Grooming & $3(11.5 \%)$ & & $2(7.7 \%)$ & $3(11.5 \%)$ & $7(27 \%)$ & $9(34.6 \%)$ & $2(7.7 \%)$ \\
\hline Bathing & $3(11.5 \%)$ & $1(3.9 \%)$ & $9(34.6 \%)$ & $3(11.5 \%)$ & $4(15.5 \%)$ & $3(11.5 \%)$ & $3(11.5 \%)$ \\
\hline Upper body dressing & $3(11.5 \%)$ & $2(7.7 \%)$ & $4(15.3 \%)$ & $7(27 \%)$ & $7(27 \%)$ & & $3(11.5 \%)$ \\
\hline Lower body dressing & $3(11.5 \%)$ & $2(7.7 \%)$ & $2(7.7 \%)$ & $9(34.6 \%)$ & $5(19.3 \%)$ & $2(7.7 \%)$ & $3(11.5 \%)$ \\
\hline Toileting & $2(7.7 \%)$ & $2(7.7 \%)$ & $6(23 \%)$ & $4(15.4 \%)$ & $6(23.1 \%)$ & $2(7.7 \%)$ & $4(15.4 \%)$ \\
\hline \multicolumn{8}{|l|}{ Sphincter control } \\
\hline Bladder management & $2(7.7 \%)$ & & & $1(3.8 \%)$ & $2(7.7 \%)$ & $3(11.5 \%)$ & $18(69.3 \%)$ \\
\hline Bowel management & $2(7.7 \%)$ & $1(3.8 \%)$ & & & $2(7.7 \%)$ & $3(11.5 \%)$ & $18(69.3 \%)$ \\
\hline \multicolumn{8}{|l|}{ Transfers } \\
\hline Bed, chair, wheelchair & $2(7.7 \%)$ & $3(11.5 \%)$ & $1(3.8 \%)$ & $1(3.8 \%)$ & & $2(7.7 \%)$ & $17(65.4 \%)$ \\
\hline Toilet & $2(7.7 \%)$ & $2(7.7 \%)$ & $2(7.7 \%)$ & & $2(7.7 \%)$ & $1(3.8 \%)$ & $17(65.4 \%)$ \\
\hline Bath, shower & $3(11.5 \%)$ & $2(7.7 \%)$ & $2(7.7 \%)$ & & & $1(3.8 \%)$ & $18(69.3 \%)$ \\
\hline \multicolumn{8}{|l|}{ Locomotion } \\
\hline Walking / wheelchair & $5(19.3 \%)$ & $1(3.8 \%)$ & & $3(11.5 \%)$ & & $5(19.3 \%)$ & $12(46.1 \%)$ \\
\hline Stairs & $7(27 \%)$ & & $1(3.8 \%)$ & $4(15.4 \%)$ & & $3(11.5 \%)$ & $11(42.3 \%)$ \\
\hline \multicolumn{8}{|l|}{ Communication } \\
\hline Comprehension & $2(7.7 \%)$ & & $2(7.7 \%)$ & $2(7.7 \%)$ & $1(3.8 \%)$ & $2(7.7 \%)$ & $17(65.4 \%)$ \\
\hline Expression & $2(7.7 \%)$ & & $2(7.7 \%)$ & $1(3.8 \%)$ & $1(3.8 \%)$ & $1(3.8 \%)$ & $19(73.2 \%)$ \\
\hline \multicolumn{8}{|l|}{ Social cognition } \\
\hline Social interaction & $1(3.8 \%)$ & $2(7.7 \%)$ & $2(7.7 \%)$ & $2(7.7 \%)$ & $4(15.4 \%)$ & $1(3.8 \%)$ & $14(53.9 \%)$ \\
\hline Problem solving & $1(3.8 \%)$ & $2(7.7 \%)$ & $6(23.1 \%)$ & $3(11.5 \%)$ & $2(7.7 \%)$ & $2(7.7 \%)$ & $10(38.5 \%)$ \\
\hline Memory & $2(7.7 \%)$ & $1(3.8 \%)$ & & & $1(3.8 \%)$ & $1(3.8 \%)$ & $21(80.9 \%)$ \\
\hline
\end{tabular}

Caption (Table 3): FIM -Functional Independence Measure; 'Scores: from 1 to 5 indicate the need for assistance and/or supervision, while scores from 6 to 7 indicate independence to perform the activity. Source: Salvador-BA, 2017. 
In our research, we attributed the difficulty in locomotion to the susceptibility found in individuals with MPS to develop musculoskeletal deformities, joint limitations, spinal cord compression and pain - conditions that have a detrimental effect on the mobility of these patients. ${ }^{1}$ With disease progression, individuals also develop low tolerance to physical exertion and locomotion difficulties, even when covering short distances, due to cardiorespiratory alterations. ${ }^{19}$ Thus, we believe that this condition restricts children and adolescents in their activities and makes it impossible for them to keep up with others of the same age group, interfering in social interaction. In addition, communication difficulties, secondary to speech disorders or decreased auditory acuity, can also interfere in the interpersonal relationships of these individuals.

The main limitations of this study are related to the reduced size of the sample, which precluded a comparison of functional independence measures between the different types of MPS; and the use of a generic assessment instrument, which does not cover specific symptoms or factors of the disease in question. However, mucopolysaccharidosis is a rare disease and the majority of studies on this condition do not involve large sample groups. Regarding the instrument used, the application of the FIM in this study is justifiable due to the lack of a specific scale, validated in Brazil, to evaluate the functional independence of patients with this disease. Nevertheless, it is hoped that this research project will help us gain a better understanding of the impacts produced by mucopolysaccharidosis on the functionality of the affected subjects.

In view of the above, it can be seen that supportive therapies for the management of patients diagnosed with MPS should not aim to simply correct the anatomical and/or clinical alterations themselves, but also to improve the functional abilities of individuals, according to their specific needs. Rehabilitation programs should provide direct intervention in the condition of incapacity and/or physical limitation to perform daily activities, especially those related to self-care; mobility/ transfers; locomotion; and social cognition - aspects compromised in these patients, as indicated by the findings of this study.

\section{CONCLUSION}

The functional independence of children and adolescents diagnosed with mucopolysaccharidoses is compromised. In the study population, we observed the need for assistance mainly in performing activities related to self-care and social cognition. Tasks related to dressing, toileting, bathing, problem solving and social interaction were those that required the most assistance and/or supervision.

AUTHORS' CONTRIBUTIONS: Each author made significant individual contributions to this manuscript. PSL (0000-0001-9434-3431)*: participated actively in the conception, analysis and interpretation of data for the work; statistical analysis; discussion of results; drafting and revision of the article; and also in the entire intellectual concept of the article; DPSF *: participated actively in the acquisition of data for the work and statistical analysis; MAAM(0000-0002-3592986X)*: participated actively in the critical review of the article and also in the entire intellectual concept. ${ }^{*}$ ORCID (Open Researcher and Contributor ID).

\section{REFERENCES}

1. Muenzer J. Overview of the mucopolysaccharidoses. Rheumatology (Oxford) 2011;50(Suppl. 5):4-12.

2. Brands MM, Güngör D, van den Hout JM, Karstens FP, Oussoren E, Plug I, et al. Pain: a prevalent feature in patients with mucopolysaccharidosis. Results of a cross-sectional national survey. J Inherit Metab Dis. 2015;38(2):323-31.

3. Guffon N, Heron B, Chabrol B, Feillet F, Montauban V, Valayannopoulos V. Diagnosis, quality of life, and treatment of patients with Hunter syndrome in the French healthcare system: a retrospective observational study. Orphanet J Rare Dis. 2015;10(43):1-13.

4. Chan MO, Sen ES, Hardy E, Hensman P, Wraith E, Jones S, et al. Assessment of musculoskeletal abnormalities in children with mucopolysaccharidoses using pGALS. Pediatr Rheumatol Online J. 2014;12(32):1-9.

5. Lehman TJ, Miller N, Norquist B, Underhill L, Keutzer J. Diagnosis of the mucopolysaccharidoses. Rheumatology (Oxford). 2011;50(Suppl. 5):41-8

6. White KK. Orthopaedic aspects of mucopolysaccharidoses. Rheumatology (Oxford). 2011:50(Suppl. 5):26-33.

7. Giugliani R, Federhen A, Rojas MV, Vieira TA, Artigalás O, Pinto LL, et al. Mucopolysaccharidosis I, II, and VI: brief review and guidelines for treatment. Genet Mol Biol. 2010;33(4):589-604.

8. Ru MH, Teunissen QG, van der Lee JH, Beck M, Bodamer OA, Clarke LA, et al. Capturing phenotypic heterogeneity in MPS I: results of an international consensus procedure. Orphanet J Rare Dis. 2012;7(1):22.

9. Peck SH, Casal ML, Malhotra NR, Ficicioglu C, Smith LJ. Pathogenesis and treatment of spine disease in the mucopolysaccharidoses. Mol Genet Metab. 2016;118(4):232-43.

10. Matos MA, Prado A, Schenkel G, Barreto R, Acosta AX. Energy expenditure during gait in patients with mucopolysaccharidosis. Acta Ortop Bras. 2013;21(2):116-9. 11. Kato T, Kato Z, Kuratsubo I, Ota T, Orii T, Kondo N, et al. Evaluation of ADL in patients with Hunter disease using FIM score. Brain Dev. 2007;29(5):298-305. 12. Yasuda E, Suzuki Y, Shimada T, Sawamoto K, Mackenzie WG, Theroux MC, et al. Activity of daily living for Morquio A syndrome. Mol Genet Metab. 2016;118(2):111-22.

13. Riberto M. Orientação funcional para utilização da MIF - Medida de Independência Funcional. 2004. [acesso em 26 mar 2016]. Disponível em: https:// toneurologiaufpr.files.wordpress.com/2013/03/manual-mif.pdf

14. Riberto M, Miyazaki MH, Jucá SS, Sakamoto H, Potiguara P, Pinto N, et al. Validação da Versão Brasileira da Medida de Independência Funcional. Acta Fisiatr. 2004;11(2):72-6.

15. Valayannopoulos V, Nicely H, Harmatz P, Tuberville S. Mucopolysaccharidosis VI. Orphanet J Rare Dis. 2010;5(5).

16. Kwon JY, Ko K, Sohn YB, Kim SJ, Park SW, Kim SH, et al. High prevalence of carpal tunnel syndrome in children with mucopolysaccharidosis type II (Hunter syndrome). Am J Med Genet A. 2011;155A(6):1329-35.

17. Amaral IA, Omena Filho RL, Reis Neto JA, Reis MC. Avaliação da capacidade funcional de adolescentes portadores de Mucopolissacaridose do tipo II. Cad Bras Ter Ocup. 2017;25(2):297-303.

18. Berger KI, Fagondes SC, Giugliani R, Hardy KA, Lee KS, McArdle C, et al. Respiratory and sleep disorders in mucopolysaccharidosis. J Inherit Metab Dis. 2013;36(2):201-10.

19. Hendriksz CJ, Lavery C, Coker M, Ucar SK, Jain M, Bell L, et al. Burden of disease in patients with Morquio A syndrome: results from an international patient-reported outcomes survey. Orphanet J Rare Dis. 2014;9(32):1-8. 